\title{
Using Rasch Model and Confirmatory Factor Analysis to Assess Instrument for Clothing Fashion Design Competency
}

\author{
K. Arasinah, Ab. R. Bakar, H. Ramlah, A. Soaib, and H. Zaliza
}

\begin{abstract}
The study aimed to determine the validity, reliability, polarity and fitness of the items, as well as to confirm the measurement model of Clothing Fashion Design Competency (CFaDC). Winsteps software was used to test the validity and reliability of the instrument, meanwhile AMOS was used to verify the measurement model. The results show the index of the items, the reliability of the individual (person) and high separation of the items and individual isolation. The results also show that the instrument is consistent, valid, stable and reliable if being administered into another sample with similar characteristics. Polarity items indicate that there were 4 knowledge items that measured other constructs and the items were dropped. A total of 31 knowledge items and 16 skills items were detected as misfit and were also dropped. Measurement model was fitted to the data and was accepted based on the suitability index (Fit Indices) that has been achieved, namely: CMIN $\chi^{2}=1306,979$, with degrees of freedom (df) 680 , CMIN/df $=1.922(<5.0)$, CFI $=0.941(>0.90)$, IFI $=.941(>0.90)$, TLI $=0.935(>0.90)$ and RMSEA $=0.053(<0.08)$. The instrument has been proven to be a good instrument and passed the psychometric standards.
\end{abstract}

Index Terms-Knowledge, Rasch model, structural equation modeling, skill.

\section{INTRODUCTION}

Competency plays an important role in every aspect of today's job. It is proven to have a positive impact on the workers, especially in educational institutions that have links related to the skills needed in the workplace [1]-[3]. The competency applied in Technical and Vocational Education (TVE) is designed to produce technical human capital that is not only technically qualified and skilled but also have high competency in technical field for their marketability [4]-[6]. Therefore, TVE educators should implement an effective teaching process and deliver the teaching in accordance to the academic standard, thus they need to master various level of competencies [7]-[9]. They also need to master certain levels of competency that has been certified by private institutions, government and training institutions involved in the job market [10].

Therefore, to acquire competent educators and have the

Manuscript received January 4, 2014; revised March 10, 2014

K. Arasinah, Ab. R. Bakar, H. Ramlah, and A. Soaib are with the Faculty of Educational Studies, University Putra Malaysia, Serdang, 43400, Selangor, Malaysia (e-mail: arasinah@gmail.com, abrb@upm.edu.my, ramlah@upm.edu.my, soaib@upm.edu.my).

H. Zaliza is with the Faculty of Technical and Vocational Education, Sultan Idris Education University, 35900, Tanjung Malim, Perak, Malaysia (e-mail: chikiza_12@yahoo.com). necessary competencies, the development of $\mathrm{CFaDC}$ instruments with high validity and reliability should be carried out. The development of $\mathrm{CFaDC}$ instruments must be suitable, stable, state-of-the-art and steady. $\mathrm{CFaDC}$ aspects are important in order to be used as a guide for educators to be able to deliver effective teaching and in line with the standard [8], [11]. Indirectly, skilled and semi-skilled worker can be produced to fulfill the industrial market needs. Meanwhile, there are various $\mathrm{CFaDC}$ instruments from abroad have been built, but there is no really legitimate instrument that has been built, and also all the instruments are too old and do not measure the competency comprehensively, for example the Clothing care on stain removal test instrument (1973), Hem construction test (1969), Wardrobe planning (1948), Basic clothing construction competencies test (1982), and Clothing placement test (1961). In addition, there is no available CFaDC instrument build in Malaysia to be used in STI. Therefore, the study of the development, instrument validation and $\mathrm{CFaDC}$ model should be carried out. The objectives of this study are to:

1) Determine the validity and reliability of $\mathrm{CFaDC}$.

2) Test the reliability and respondents' item seperation index.

3) Determine and detect the item polarity of $\mathrm{CFaDC}$.

4) Detect the suitability of $\mathrm{CFaDC}$ item.

5) Validate the $\mathrm{CFaDC}$ measurement model.

\section{Methodology}

This study used a form of quantitative approach by survey method using questionnaires. The respondents consist of 330 instructors at STI in Malaysia that were selected by simple random sampling. The instrument consists of 157 items, which are 85 knowledge items (dichotomous), and 72 skill items (polytomous). The data were analyzed using the Rasch measurement model (Winsteps version 3.72.3) in the first stage and Structural Equation Modeling analysis using AMOS software (version 21) in the second stage.

\section{RESUlt AND Discussion}

In the first stage, the data was analyzed using the Rasch measurement model. Knowledge items consist of 5 subconstruct with 85 items of: 1) Design: 10 items, 2) Clothing construction: 40 items, 3) Clothing Selection: 9 items, 4) Clothing Care: 12 items, and 5) Textile Evaluation: 14 items. Knowledge items were in the dichotomous form, which are multiple choices, matching, right-wrong and filling 
in the blank. Meanwhile, skill items were in polytomous form with the four score Likert scale designed based on category of: 1) not competent, 2) moderately competent, 3) competent, 4) very competent. Skill items consist of 6 constructs with 72 items of: 1) Designing (DS): 13 items, 2) Pattern drafting (PD): 14 items, 3) Sewing (SS): 8 items, 4) Computer (CS): 6 items, 5) Creative (CR): 10 items, and 6) Trade (TR): 21 items.

\section{A. Analysis Using Rasch Measurement Model}

The first stage was the process of analyzing data using Rasch measurement model to test the reliability of the instrument as shown in Table I. Table I shows the reliability index for the interpretation of knowledge competency items ( 85 items) of 0.99 , while for the assessment of competency skills (72 items) was about 0.99 . The reliability of the respondents for the assessment of knowledge competency was 0.84 and the skills competency assessment was 0.98 . This indicates that these instruments are consistent and stable if administered in other samples that have the same and nearly similar features. The reliability index is parallel with CFaDC instruments as suggested by [12]-[15], which stated that the respondents and item reliability index $>0.8$ is an acceptably good and high index.

Meanwhile, the index of item separation was 8.38 for items of knowledge and skills items was 9.64, which statistically means that $\mathrm{CFaDC}$ items are distinguished based on the 8 and 9 levels of different measurement. Respondents separation index (person separation) for knowledge items was 2.2 and skill items was 6.51 , which shows the ability of the respondents can be divided into 2 and 6 levels of ability to answer the competency item. The findings are in line with the recommendations by [13], [16] whom stated that the value of individual and item separation exceeds the value of 2 is considered good. Meanwhile, [12] also recommends the value of individual and items separation between 2 to 3 is moderately good and more than 5 is excellent. The higher the level of item separation, thus the measurement instrument is better as they are separated with varying difficulty.

Meanwhile, the polarity of the items shown by the PTMEA Corr value as mentioned by [17] that PTMEA CORR negative value indicates the item is not moving in line with other items to measure the constructs. Therefore, out of the 85 knowledge items, 4 items have negative PTMEA CORR value and were omitted because these items measured other constructs. A total of 81 moving items measured 5 knowledge subconstruct, where the PTMEA CORR values were between -0.02 to 0.54 . Meanwhile, all 72 skill items have strong positive PTMEA CORR values between 0.47 to 0.73 . This means that all skill items moved in line or to the same direction with other items in measuring the skills construct more meaningfully. Thus, 81 knowledge items and 72 skill item statistically indicated that the items moved in a desired direction. These items were not in conflict with the intended $\mathrm{CFaDC}$ constructs to be measured.

The suitability of the item (item fit) was based on the Outfit / Infit MNSQ index. The acceptable range for the item fit to the Likert scale (polytomous) is between 0.6 logits to 1.4 logits and for dichotomous data is between 0.7 to 1.3 logits as proposed by [13] and [18]. The higher value indicates the item is not homogeneous with other items in a scale of measurement. The low value indicates redundancy constructs with other items. The results in Table I explained out of 85 knowledge items, 31 items were detected as misfit, while from 72 skill items, 16 items were detected as misfit. Hence, only 54 knowledge items and 56 skill items contributed to the construction of $\mathrm{CFaDC}$ competency subconstruct.

TABLE I: SUMMARY OF THE VALIDITY AND RELIABILITY OF THE ITEMS USING RASCH MODEL

\begin{tabular}{|c|c|c|c|c|}
\hline \multirow[t]{2}{*}{ No } & \multirow[t]{2}{*}{ Objective } & \multicolumn{2}{|c|}{ Results } & \multirow{2}{*}{$\begin{array}{c}\text { Acceptance } \\
\text { Level }\end{array}$} \\
\hline & & $\begin{array}{l}\text { Knowledge } \\
\text { (85 items) }\end{array}$ & $\begin{array}{c}\text { Skill } \\
(72 \text { items })\end{array}$ & \\
\hline \multicolumn{5}{|c|}{ Reliability } \\
\hline \multirow[t]{5}{*}{$2 \mathrm{a}$} & \multicolumn{4}{|c|}{ Reliability test and item separation index of respondents. } \\
\hline & $\begin{array}{l}\text {-Item's } \\
\text { reliability }\end{array}$ & $0.99(\mathrm{KR} 20)$ & 0.99 & $\begin{array}{c}>.70 \\
{[12]-[15]}\end{array}$ \\
\hline & $\begin{array}{l}\text {-Respondents' } \\
\text { reliability }\end{array}$ & 0.84 & 0.98 & \\
\hline & $\begin{array}{l}\text {-Item } \\
\text { separation } \\
\text { index }\end{array}$ & 8.38 & 9.64 & $\begin{array}{c}>2.0 \\
{[13],[16]}\end{array}$ \\
\hline & $\begin{array}{l}\text {-Respondents' } \\
\text { separation } \\
\text { index }\end{array}$ & 2.25 & 6.51 & $\begin{array}{l}>2.0 \\
{[12]}\end{array}$ \\
\hline \multicolumn{5}{|c|}{ Fit item validity } \\
\hline \multirow[t]{3}{*}{$2 b$} & \multicolumn{4}{|c|}{ To determine and detect the polarity of CFaDC competency item. } \\
\hline & $\begin{array}{l}\text {-To what } \\
\text { extent do the } \\
\text { items moved } \\
\text { in one } \\
\text { direction to } \\
\text { interpret the } \\
\text { constructs? }\end{array}$ & $\begin{array}{c}-0.02-0.54 \\
\text { (4 negative } \\
\text { items } \\
\text { omitted) } \\
\text { (81 positive } \\
\text { index items) }\end{array}$ & $\begin{array}{c}0.47-0.73 \\
\text { (72 positive } \\
\text { index items) }\end{array}$ & $\begin{array}{l}\text {-PTMEA Corr } \\
\text { (positive } \\
\text { values ) } \\
{[17]}\end{array}$ \\
\hline & $\begin{array}{l}\text {-To what } \\
\text { extent do the } \\
\text { items } \\
\text { contribute } \\
\text { towards the } \\
\text { constructs } \\
\text { measured? }\end{array}$ & $\begin{array}{l}54 \text { out of } 85 \\
\text { items } \\
\text { measured } \\
\text { construct }\end{array}$ & $\begin{array}{c}-56 \text { out of } 72 \\
\text { items } \\
\text { measured } \\
\text { construct }\end{array}$ & \\
\hline $2 \mathrm{c}$ & \multicolumn{4}{|c|}{ Detect the suitability/fit of $\mathrm{CFaDC}$ competency items. } \\
\hline & $\begin{array}{l}\text { To what extent } \\
\text { do the items fit } \\
\text { with the } \\
\text { measurement } \\
\text { model? }\end{array}$ & $\begin{array}{l}31 \text { items } \\
\text { misfit }\end{array}$ & $\begin{array}{l}16 \text { items } \\
\text { misfit }\end{array}$ & $\begin{array}{l}\text { Infit loutfit } \\
\text { MNSQ } \\
-0.7-1.3 \\
\text { (dichotomous) } \\
{[13]} \\
-0.6-1.4 \\
\text { (polytomous) } \\
{[13],[18]} \\
\end{array}$ \\
\hline
\end{tabular}

\section{B. Analysis Using Structural Equation Modeling (SEM)}

Further analysis used Structural Equation Modeling (SEM) to ensure the findings meet the accuracy and consistency. Confirmatory Factor Analysis (CFA) was used to test the construct validity of the skill competency items with Likert scale. The skill items acquired were consistent and have good internal validity, which is through the convergent and discriminant validity. The findings of the CFA determined that out of the 56 items, only 34 skill items have good and acceptable convergent validity and discriminant validity.

The final analysis to confirm the measurement model CFaDC was by using AMOS. As [19] suggested to check the suitability (fit) measurement model, the analysis is dependent on the suitability index (fitness index). At least 3 or 4 fitness indices criteria must be met as shown in Table II. The 
individual measurement values (person measure) were entered into SPSS and then the data were analyzed using AMOS. As [19] suggested reporting Chi Square / df (Parsimonious fit), CFI or TLI (Incremental Fit) and RMSEA (Absolute fit) is sufficient to evaluate the measurement model.

CFaDC measurement model obtained 41 degree of freedom and Chi square goodness-of-fit statistics, $(N=330$, $d f=680)=1306.979, p=<0.00$. The results show that this model obtained Chi square value of 1306.979 , degree of freedom is 680, and the level of probability (probability level) was .000. Fig. 1 shows a model of CFaDC competency measurement containing 5 subsconstructs of knowledge competency and 6 subconstructs of skill competency. The knowledge items contained 54 items of Design (8 items), Tailoring (27 items), Cloth Selection (5 items), Clothing Care (8 items), and Textile Evaluation (6 items). Meanwhile, the skill items consisted of 33 items of Designing (8 items), Pattern Drawing (4 items), Sewing (6 items), Creative (4 items), Trade (9 items), and Computer (4 items).

TABLE II: CRITERIA FOR SUITABILITY INDEX (FIX INDICES)

\begin{tabular}{|c|c|c|c|c|}
\hline $\begin{array}{l}\text { Suitability } \\
\text { index }\end{array}$ & Measurement & $\begin{array}{c}\text { Referenc } \\
\text { e }\end{array}$ & $\begin{array}{l}\text { Suggested } \\
\text { value }\end{array}$ & Comment \\
\hline $\begin{array}{c}\text { CMIN/ } \\
\text { DF }\end{array}$ & 1.922 & $\begin{array}{l}{[20]} \\
{[21]}\end{array}$ & $\begin{array}{c}\leq 5.0 \\
\leq 5.0 \\
\text { Report if } \\
\text { the } \\
\text { sample } \\
\text { number } \\
>200\end{array}$ & $\begin{array}{l}\text { The value must } \\
\text { be } \leq 5.0\end{array}$ \\
\hline IFI & .941 & $\begin{array}{l}{[22]} \\
{[23]}\end{array}$ & $\begin{array}{l}\geq .90 \\
\geq .90\end{array}$ & $\begin{array}{l}\text { IFI } \geq .941 \text { is a } \\
\text { good fit }\end{array}$ \\
\hline CFI & .941 & $\begin{array}{l}{[21]} \\
{[24]}\end{array}$ & $\begin{array}{l}\geq .90 \\
\geq .90\end{array}$ & $\begin{array}{l}\mathrm{CFI} \geq .941 \text { is a } \\
\text { good fit }\end{array}$ \\
\hline TLI & .935 & [25] & $\geq .90$ & $\begin{array}{l}\text { TLI } \geq .935 \text { is a } \\
\text { good fit }\end{array}$ \\
\hline RMSEA & .053 & $\begin{array}{l}{[26]} \\
{[27]}\end{array}$ & $\begin{array}{l}\leq .08 \\
\leq .95\end{array}$ & $\begin{array}{l}\text { RMSEA } \leq .08 \\
\text { accepted and is } \\
\text { a good fit }\end{array}$ \\
\hline
\end{tabular}

DF (degree of freedom), CFI (Comparative of Fit Index), TLI

(Tucker-Lewis Index), RMSEA (Root mean square error of approximation)

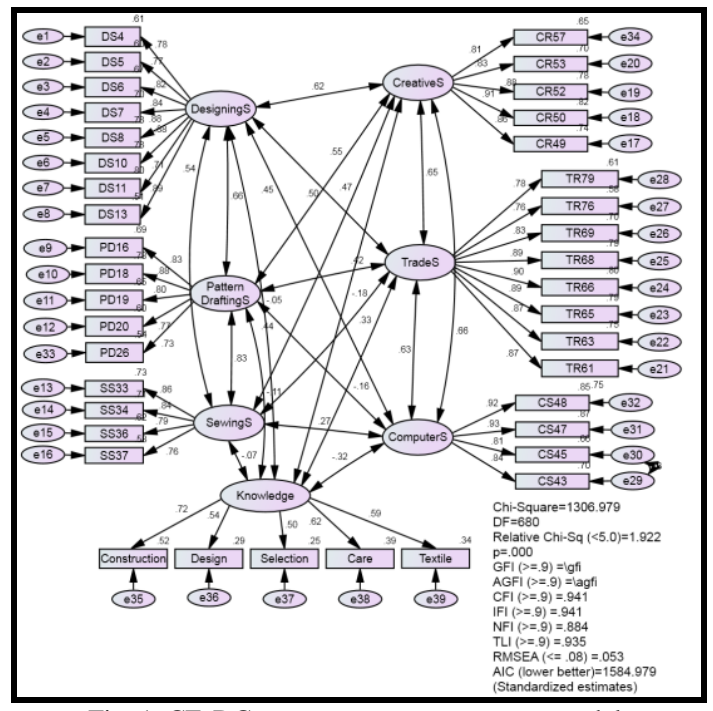

Fig. 1. CFaDC competency measurement model.

Fig. 1 also shows the model is fit with the data and accepted based on the suitability index (fit), which is: CMIN $\chi^{2}=1306.979$ with the degree of freedom of $(d f) 680$, $\mathrm{CMIN} / \mathrm{df}=1.922 \quad(\leq 5.0), \quad \mathrm{CFI}=0.941 \quad(\geq 0.90), \quad \mathrm{TLI}=0.935$ $(\geq 0.90)$, IFI $=0.941 \quad(\geq 0.90)$, and RMSEA $=0.035(\leq 0.08)$. Furthermore, the weighting factor was between 0.502 to 0.935. The $\mathrm{CFaDC}$ instrument consists of 11 subconstructs with 88 items, 54 knowledge competency items, and 34 skill competency items.

\section{CONCLUSION}

The validity and reliability of each item in the instrument is very important. The psychometric properties are proofs of high validity and reliability. The results of analysis using the Rasch measurement model achieved an index of the items reliability, the reliability of an individual (person), the item separation and the relatively high individual separation of knowledge and skill items. This shows CFaDC instrument is reliable and valid. Meanwhile, although most of the items moved in a similar direction, there are also a few items that do not contribute meaningfully to the measurement for the desired construct.

The researcher also ensures that each items is unidimensional naturally, have different levels of difficulty, fair to all individuals who answered the built instrument. In addition, the reliability of the items and the respondent is to be taken seriously to ensure that the built instrument and respondents are consistent. The instrument can also produce a more meaningful measurement. Analysis result using the Rasch model found the $\mathrm{CFaDC}$ instrument have good construct validity and are acceptable. Further analysis of the CFA on 56 skill items with Likert scale found that only 34 items obtained good internal consistency and validity through convergent and discriminant validity. Furthermore, $\mathrm{CFaDC}$ measurement model consists of 5 subconstructs of knowledge competency (56 items) and 6 subconstruct of skill competency (34 items). The model was fit to the data and was based on the suitability index (fit) achieved, namely: $\chi^{2}$ CMIN, CMIN / df, CFI, IFI, TLI, and RMSEA.

The findings of this study would provide new leads to the robustness of the competency standard for $\mathrm{CFaDC}$ program so that it is always updated and in sync with the needs of industry, Institute of Teacher Education, the profession of fashion in STI and the schools in Malaysia. The findings are also expected to contribute to the preparation of fashion program for teachers, educators and trainers in schools and in the STI by modifying the existing competencies in the curriculum. Thus, the robust $\mathrm{CFaDC}$ instrument, legitimate and fair can be practiced at STI, which emphasizes the skills and knowledge components that can still be explored. Therefore, the development of $\mathrm{CFaDC}$ instrument can improve the content scope of the practice competency constructions, which can still be refined and explored. This exploration provides opportunities to enrich the theory or $\mathrm{CFaDC}$ model alongside the enhancement to the construction content competencies with more broader scope besides assessing the level of competency of instructors in STI.

\section{ACKNOWLEDGMENT}

Arasinah, K. Author thanks to all the individuals involved 
in helping to obtain all the needed information and the supervisor of this research. The authors(s) received no financial support for the research and/or authorship of this article.

\section{REFERENCES}

[1] M. Mulder, "Competentie on twikkeling in organisaties: perspectieven en practijk," The Hague: Elsevier Bedrijfsinformatie, 2001. in E. Roelofs and P. Sanders, "Towards a framework for assessing teacher competence," European Journal of Vocational Training, vol. 40, pp. 123-139, 2007.

[2] R. Palan, Competency Management: A Practitioner's Guide, Kuala Lumpur, Malaysia: Specialist Management Resources, 2003, ch. 1, pp.14-20.

[3] M. Lai and N. K. Lo, "Perceived workplace competences ata three sites on the Chinese mainland," Journal of Vocational Education and Training, vol. 60, no. 2, pp. 89-204, 2008.

[4] J. W. Rojewski, "Preparing workforce for tomorrow: Conceptual framework for career and technical education," Journal of Vocational Education Research, vol. 27, no. 1, pp. 7-35, 2002.

[5] RMK Ke-10. (January 2011). (In Malay). Rancangan Malaysia ke Sepuluh 2011-2015. Kementerian Sumber Manusia. [Online] Available:

http://www.pmo.gov.my/dokumenattached/RMK/RMK10_Mds.pdf

[6] K. M. Salleh and N. L. Sulaiman, "Penilaian kemahiran teknikal berasaskan model kompetensi bagi sumber tenaga kerja menerusi pendekatan pendidikan teknik dan vokasional di Malaysia," in Monograf Persidangan Pengajaran dan Pembelajaran di Peringkat Pengajian Tinggi, in Malay, Universiti Putra Malaysia, 2007, pp. 148-157.

[7] M. J. Pickard, "Action research: Holding up the mirror to examine FCS teacher preparation," Journal of Family and Consumer Science, vol. 22, no. 2, pp. 12-46, 2004.

[8] K. Davis, "Teacher education priorities of family and consumer sciences teacher education program: A modified Delphi study,' Journal of Family and Consumer Science Education, vol. 28, no. 2, pp. $1-13,2010$.

[9] L. Wheelahan and G. Moodie. (July 2010). The quality of teaching in VET. [Online]. Available: https://austcolled.com.au/announcement/study-quality-teaching-vet

[10] P. Jordi, "Challenges of the recognition acquired informally and non-formally by vocational education and training teachers: Reflections based on the EU's experience," Journal of Educational and Training, vol. 1, no. 1, pp. 29-36, 2009.

[11] C. L. Lee, "Competencies in clothing and textiles needed by beginning family and consumer science teachers," Journal of Family and Consumer Science Education, vol. 20, no. 1, pp. 27-31, 2002.

[12] W. P. Jr. Fisher. (2007). Rating scale instrument quality criteria. Rasch Measurement Transaction. [Online]. 21(1). pp. 1095. Available: http://www.rasch.org/rmt/rmt $211 \mathrm{~m} . \mathrm{htm}$

[13] T. G. Bond and C. M. Fox, Applying the Rasch Model: Fundamental Measurement in the Human Sciences, $2^{\text {nd }}$ ed. Mahwah, New Jersey.: Lawrence Erlbaum Associates, 2007, ch. 3, pp. 40-48.

[14] J. F. Pallant and A. Tennant, "An introduction to the Rasch measurement model: An example using the Hospital Anxiety and Depression Scale (HADS)," Br J Clin Psychol, vol. 46, no. 1, pp. 1-18, 2007.

[15] R. F. de Vellis, Scale Development: Theory and Applications, $3^{\text {rd }}$ ed. Thousand Oaks, CA: Sage Publications, 2012, ch. 3, pp. 31-58.

[16] J. M. Linacre. (2004). Test validity, and Rasch measurement: Construct, content, etc. Rasch Measurement Transactions. [Online]. 18(1). pp. 970-971. Available: http:www.rasch.org/rmt/rmt162fht $m$

[17] J. M. Linacre, Winsteps Rasch Measurement (Version 3.7.1.1) [Computer Software], Chicago: Winsteps.com, 2010.

[18] J. M. Linacre. (2002). What do infit and outfit, mean-square and standardized mean? Rasch Measurement Transaction. [Online]. 16(2). pp. 878. Available: http:www.rasch.org/rmt/rmt $162 \mathrm{fhtm}$

[19] J. F. Hair, B. Black, B. Babin, R. E. Anderson, and R. L. Tatham, Multivariate Data Analysis: A Global Perspective, $7^{\text {th }}$ ed. New Jersey, USA: Pearson Education Inc, 2010, ch. 11, pp. 638-660.

[20] H. W. Marsh and D. Hocevar, "Application of confirmatory factor analysis to the study of self-concept: First and higher-order factor models and their invariance across groups," Psychological Bulletin, vol 97 , no. 3, pp. 562-582, 1985

[21] P. M. Bentler, "Comparative fit indexes in structural models," Psychological Bulletin, vol. 107, pp. 238-246, 1990.
[22] P. Chau, "Reexamining a model for evaluating information center success using a structural equation modeling approach," Decision Science, vol. 2, pp. 309-333, 1997.

[23] A. H. Segars and V. Grover, "Re-examining perceived ease of use and usefulness: A confirmatory factor analysis," MIS Quarterly, vol. 17, no. 4, pp. 517-525, 1993.

[24] L. Hatcher, "A step-by-step approach to using SAS for factor analysis and structural equation modeling," Cary, NC: SAS Institute Inc, 1994 ch. 5, pp. $259-264$

[25] P. M. Bentler and D. G. Bonnet, "Significance tests and goodness-of-fit in the analysis of covariance structures," Psychological Bulletin, vol. 88, pp. 588-606, 1980.

[26] B. M. Byrne, Structural Equation Modeling with AMOS: Basic Concepts, Applications, and Programming, $2^{\text {nd }}$ ed. New York, London: Taylor and Francis Group, 2010, ch. 5, pp.112-117.

[27] L. Hu and P. M. Bentler, "Cutoff criteria for fit indexes in covariance structure analysis: Conventional criteria versus new alternatives," Structural Equation Modeling, vol. 6, pp. 1-55, 1999.

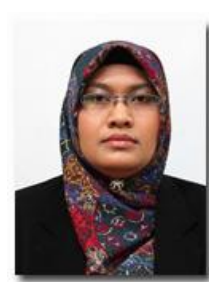

K. Arasinah has obtained her bachelor's degree in Fashion Design (UiTM Malaysia) in 1998 and obtained her master's degree in technical and vocational education in the field of home science education from University Putra Malaysia in 2010. Mrs. K. Arasinah has received the copyright award for the $\mathrm{CFaDC}$ instrument in 2013 from Research Management Centre, University Putra Malaysia for the product "Clothing Fashion Design Competency Instrument (LY2013001188)". She is a PhD candidate and tutor at the Department of Science and Technical Education, University Putra Malaysia. Her field of interest is fashion and apparel which include clothing designs, sketches, patterns of clothing and apparel management. She has experience in different apparel industries as a fashion designer.

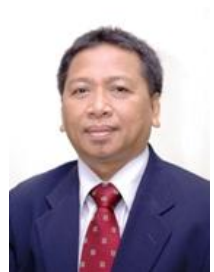

Ab. R. Bakar is a professor in the Department of Science and Technical Education, University Putra Malaysia in the field of technical education and vocational / career development. His researches are in the fields of career development, staff development, vocational education, employability skills and teacher's development.

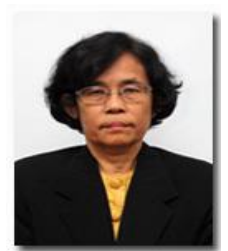

H. Ramlah is an associate professor in the Department of Science and Technical Education, University Putra Malaysia in the field of vocational and technical education-agriculture education. Her researches are in the fields of vocational and technical education, agriculture education and teaching and learning.

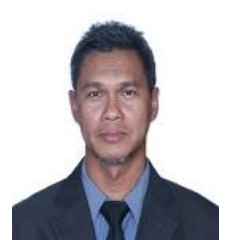

A. Soaib is a senior lecturer in the Department of Foundation Education, University Putra Malaysia in the field of educational administration. His research interests are in the areas of university governance, higher education management leadership, quality management in higher education and entrepreneurship and entrepreneurship education

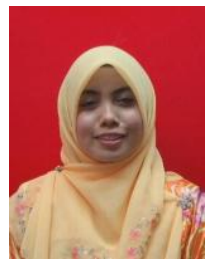

H. Zaliza has obtained her bachelor's degree in the field of Technical and Vocational Education (Civil Engineering) in 2007 from Universiti Tun Hussein Onn, Malaysia and in 2010, she earned her master's degree in the same field from Universiti Putra Malaysia Currently, she is a PhD student at Universiti Teknologi Malaysia and a lecturer in Faculty of Technical and Vocational Education, Sultan Idris Education University, Malaysia. Her fields of research interest are curriculum development, psychology, human capital development and career, especially in the engineering field. 